Revta brasil. Bot., São Paulo, V.24, n.1, p.79-84, mar. 2001

\title{
Germination of seeds of tropical pioneer species under controlled and natural conditions
}

\author{
IVANY FERRAZ MARQUES VÁLIO ${ }^{1,2}$ and FABIANO MICHELETTO SCARPA ${ }^{1}$
}

(received: April 20, 2000; accepted: October 7, 2000)

\begin{abstract}
Germination of seeds of tropical pioneer species under controlled and natural conditions). Seed germination of eight tropical pioneer species (Cecropia hololeuca, C. pachystachya, C. glazioui, Solanum gracillimum, S. granuloso-leprosum, S. tabacifolium, Croton floribundus and Miconia chamissois) was studied. In controlled conditions, alternating temperatures were tested from 5 to $25^{\circ} \mathrm{C}$. Low Red:Far Red ratios (R:FR) were also examined. In the field, germination was evaluated in gaps and under the canopy. With the exception of Croton floribundus, all other species were photoblastic in that higher germination percentages were found under light conditions ( $S$. tabacifolium behaved as a negative photoblastic species at some temperatures). No relationship was found between germination percentage and alternating temperature. Germination was markedly reduced under low R:FR ratios. Alternating temperature is not the main factor affecting field germination. The low R:FR ratio under the canopy seems to be the crucial factor affecting germination.
\end{abstract}

RESUMO - (Germinação de sementes de espécies pioneiras tropicais sob condições controladas e naturais). Foi estudada a germinação de sementes de oito espécies de pioneiras tropicais (Cecropia hololeuca, C. pachystachya, C.glazioui, Solanum gracillimum, S. granuloso-leprosum, S.tabacifolium, Croton floribundus e Miconia chamissois). Em condições controladas, foram testadas temperaturas alternadas usando amplitudes que variaram de 5 a $25^{\circ} \mathrm{C}$. Também foram testadas baixas razões de vermelho:vermelho extremo. Em condições naturais, a germinação foi testada em clareira e sob o dossel. Com exceção de Croton floribundus, todas as outras espécies se mostraram fotoblásticas, sendo que altas porcentagens de germinação foram encontradas sob condições de luz ( $S$. tabacifolium comportou-se como espécie fotoblástica negativa em algumas temperaturas). Não foi encontrada relação entre porcentagens de germinação e amplitude de temperaturas. A germinação foi drasticamente reduzida sob baixas razões de vermelho:vermelho extremo. Alternância de temperatura não foi o principal fator a influenciar a germinação em condições naturais. A baixa razão vermelho:vermelho extremo prevalecente sob o dossel parece ser o fator crucial que afeta a germinação.

Key words: Pioneer species, germination, alternating temperatures, gap and understory environments

\section{Introduction}

The genus Cecropia (Cecropiaceae) is represented from Central to Southern Brazil by three species: C. hololeuca, C.glazioui and C. pachystachya. Cecropia hololeuca and C. glazioui are tall trees usually found in small gaps in well drained forests while $C$. pachystachya is shorter with many lateral branches and found in large gaps, open areas, river banks and permanently flooded areas. Only Cecropia glazioui and C. pachystachya are mirmecophyllous species. Individuals of these species flower and fruit almost continuously all year round. Numerous small seeds are produced in the fruits and are dispersed by birds and bats (Gandolfi 2000).

1. Universidade Estadual de Campinas, Instituto de Biologia, Departamento de Fisiologia Vegetal, Caixa Postal 6109, 13083-970 Campinas, SP, Brasil. Fax: (019) 2893124.

2. Autor para correspondência: valio@obelix.unicamp.br
The solanaceous species, Solanum granulosoleprosum and S. tabacifolium, are small trees while $S$. gracillimum is a common shrub in gaps and forest edges. These species produce fleshy fruits with many small seeds which are dispersed by birds and probably bats. Individuals of $S$. granuloso-leprosum flower and fruit almost year around while $S$. gracillimum and $S$. tabacifolium flower and fruit only once a year. Nevertheless, maturation of the fruits is not synchronous, the plants bearing fruits for long periods (Gandolfi 2000).

Miconia chamissois (Melastomataceae) is a shrub usually found in gaps and forest edges. It flowers and fruits once a year. The fleshy fruits bear large numbers of very small seeds, which are dispersed by birds.

Croton floribundus (Euphorbiaceae) is a tall tree commonly found in gaps. The seeds are much larger than the other species and its dispersal occurs by autochory (explosive type, according to Van der Pijl 1982).

All these species are common in secondary vegetation in the tropical rainforest, exerting strong 
quantitative dominance in early secondary succession after disturbance (Stutz de Ortega 1990, Castelani \& Stubblebine 1993), and their seeds are abundant in persistent seed banks in the forest soil (Holthijzen \& Boerboom 1982, Grombone-Guaratini 1999). These species can be considered pioneers since they fulfil some of the requirements proposed by Swaine \& Whitmore (1988), such as: frequent production of abundant small seeds; light-sensitive seeds; anemochoric or zoochoric dispersion; shadeintolerant plants; fast growth; phenotypic plasticity, etc.

Light is one of the main factors controlling dormancy in seeds. The light response of seeds can control the timing of germination in the field, a decisive factor for the survival of the seedlings. The effect of light on seeds depends on genotype and on environmental factors during the ontogenesis of the seed, inducting dormancy and germination itself. These environmental factors are not constant in time in the field and an analysis of what is actually happening with a seed in natural conditions and the possible ecological significance of a light response is very difficult to determine (Pons 1992).

The objective of this paper was to study the effects of light and alternating temperatures on seed germination of eight tropical pioneer species, under controlled and natural conditions

\section{Material and methods}

Seeds of the pioneer species Solanum gracillimum Sendt., S. tabacifolium Salsm., S. granuloso-leprosum Dun., Cecropia hololeuca Miq., C. glazioui Snethl., C. pachystachya Trec., Croton floribundus Lund. and Miconia chamissois Naud. were collected in the Mata de Santa Genebra (22 $2^{\circ} 49^{\prime} \mathrm{S}$ and $\left.47^{\circ} 06^{\prime} \mathrm{W}\right)$, Southeast of Brazil. In the laboratory, the seeds were cleaned and maintained in a refrigerator for about two months (inside plastic bags at approximately $9^{\circ} \mathrm{C}$ ) before use. Seeds were placed in Petri dishes on filter paper wetted with distilled water after surface sterilization for $15 \mathrm{~min}$ in a $5 \%$ solution of sodium hypochlorite. The experiments were conducted in incubators and in natural conditions in gaps and under the forest canopy. Temperature in the incubators was maintained at constant $\left(25^{\circ} \mathrm{C}\right)$ or alternating $\left(30 / 20,30 / 15,30 / 10,35 / 15,35 / 10^{\circ} \mathrm{C}\right)$ temperatures over $12 \mathrm{~h}$ light (higher temperature) and $12 \mathrm{~h}$ dark (lower temperature) periods, respectively. Light was supplied by fluorescent lamps with an irradiance of about $20 \mu \mathrm{mol} \cdot \mathrm{m}^{-2} \cdot \mathrm{s}^{-1}$. In the experiment with low ratios of Red (R) and Far Red (FR) the Petri dishes were maintained in incubators under continous incandescent lights: the R:FR ratio of transmitted light in Petri dishes wrapped with a transparent colorless cellophane paper was 0.6 and under red plus blue cellophane papers was 0.1 .

The R:FR ratio $(650: 730 \mathrm{~nm})$ was recorded by a Li-COR 1800 spectroradiometer. For the dark treatments, the Petri dishes were placed inside opaque black polyethylene bags. Usually four replicates of 20 seeds each were used per treatment. Experimental duration was about 6 weeks.

In the forest (Mata de Santa Genebra), the Petri dishes in plastic trays were maintained in a gap and under the canopy. Recorded temperatures near the Petri dishes showed a maximum of $35^{\circ} \mathrm{C}$ and a minimum of $17^{\circ} \mathrm{C}$ for the gap and $35^{\circ} \mathrm{C}$ and $11^{\circ} \mathrm{C}$, respectively under the canopy. In the gap in which the seeds were maintained the R:FR ratio of the incident vertical light was 1.58 , while lateral and diffuse light close to the soil was on average 0.25 . Under the canopy, the incident light was 0.36 and the lateral and diffuse light no greater than 0.11 .

Germinated seeds were recorded weekly until the end of the experiments, considering germinated any seed with at least $1 \mathrm{~mm}$ of radicle growth.

Final germination percentages were transformed in $\arcsin \sqrt{\mathrm{P}}$ and the data subjected to an analysis of variance. The Tukey test at the $5 \%$ level was used to compare means when "F" was significant.

\section{Results}

The germination of Cecropia species was relatively fast under light, beginning after one week of incubation and stabilizing at high levels after four weeks. At a constant temperature of $25^{\circ} \mathrm{C}$, these species were photoblastic (table 1). No germination occurred under darkness. Under alternating temperatures, this photoblastic behaviour was maintained but some germination occurred in darkness for $C$. hololeuca and C. pachystachya. These germination percentages were variable and no relationship was obtained between values or range of temperatures and germination. Germination of C. glazioui was more restricted in relation to light. In all alternate pair of temperatures, germination occurred only under light/dark condition (table 1). A similar pattern of germination was observed under natural conditions. High germination percentages occurred in the gap and almost no germination was found in deep shade (less than $3 \%$ of the radiation above the canopy) under the canopy (table 2). Lowering the R:FR ratio to 0.6 (about half of natural sunlight) had little effect on germination, but when this ratio was reduced to one tenth, germination was drastically reduced (table $3)$.

When compared to Cecropia species, the Solanum species were slow to germinate. Germination began between the second and third week of 
Table 1. Seed germination (\%) of eight tropical pioneer species under different temperature and light regimes.

\begin{tabular}{|c|c|c|c|c|c|c|c|c|c|}
\hline Temp ${ }^{\circ} \mathrm{C}$ & Light regime & $\mathrm{CH}$ & $\mathrm{CP}$ & CG & SG & SGL & ST & $\mathrm{CRF}$ & MC \\
\hline \multirow[t]{2}{*}{$30 / 10$} & L/D & $97.5 \mathrm{a}$ & $90.0 \mathrm{ab}$ & --- & $91.2 \mathrm{a}$ & $92.0 \mathrm{a}$ & $93.7 \mathrm{a}$ & --- & --- \\
\hline & $\mathrm{D}$ & $20.0 \mathrm{~d}$ & $60.0 \mathrm{~d}$ & --- & $92.5 \mathrm{a}$ & $57.5 \mathrm{c}$ & 85.0ab & --- & --- \\
\hline \multirow[t]{2}{*}{$30 / 15$} & $\mathrm{~L} / \mathrm{D}$ & $85.0 \mathrm{a}$ & $78.0 \mathrm{c}$ & $78.0 \mathrm{a}$ & $31.2 \mathrm{c}$ & $81.2 \mathrm{~b}$ & $21.2 \mathrm{~d}$ & $80.0 \mathrm{~b}$ & --- \\
\hline & $\mathrm{D}$ & $8.7 \mathrm{~d}$ & $3.7 \mathrm{f}$ & $0.0 \mathrm{~b}$ & $3.7 \mathrm{e}$ & $28.7 \mathrm{~d}$ & $90.0 \mathrm{a}$ & $87.5 \mathrm{ab}$ & --- \\
\hline \multirow[t]{2}{*}{$30 / 20$} & L/D & $92.5 \mathrm{a}$ & $77.5 \mathrm{c}$ & $82.2 \mathrm{~b}$ & $73.7 \mathrm{~b}$ & $63.7 \mathrm{c}$ & $22.5 d$ & $100.0 \mathrm{a}$ & $80.0 \mathrm{a}$ \\
\hline & $\mathrm{D}$ & $76.2 \mathrm{~b}$ & $50.0 \mathrm{~d}$ & $0.0 \mathrm{~d}$ & $10.0 \mathrm{~d}$ & $16.2 \mathrm{e}$ & $100.0 \mathrm{a}$ & $90.0 \mathrm{a}$ & $0.0 \mathrm{c}$ \\
\hline \multirow[t]{2}{*}{$30 / 25$} & L/D & $91.2 \mathrm{a}$ & $76.2 \mathrm{c}$ & $100.0 \mathrm{a}$ & $35.0 \mathrm{c}$ & $8.7 \mathrm{e}$ & $17.5 \mathrm{~d}$ & --- & --- \\
\hline & $\mathrm{D}$ & $81.2 \mathrm{~b}$ & $21.2 \mathrm{e}$ & $80.0 \mathrm{~b}$ & $1.2 \mathrm{e}$ & $8.7 \mathrm{e}$ & $82.5 b$ & --- & --- \\
\hline \multirow[t]{2}{*}{$35 / 10$} & L/D & $100.0 \mathrm{a}$ & $81.2 \mathrm{bc}$ & --- & $95.0 \mathrm{a}$ & $82.5 \mathrm{a}$ & $76.2 b$ & --- & --- \\
\hline & D & $62.5 \mathrm{c}$ & $60.0 \mathrm{~d}$ & --- & $77.5 \mathrm{~b}$ & $55.0 \mathrm{c}$ & $81.2 \mathrm{~b}$ & --- & --- \\
\hline \multirow[t]{2}{*}{$35 / 15$} & L/D & $95.0 \mathrm{a}$ & $98.7 \mathrm{a}$ & $70.0 \mathrm{c}$ & $75.0 \mathrm{~b}$ & $76.2 \mathrm{~b}$ & $75.0 \mathrm{~b}$ & --- & ---- \\
\hline & $\mathrm{D}$ & $11.2 \mathrm{~d}$ & $57.8 \mathrm{~d}$ & $0.0 \mathrm{~d}$ & $21.2 \mathrm{c}$ & $27.5 \mathrm{~d}$ & $46.2 \mathrm{c}$ & --- & --- \\
\hline \multirow[t]{2}{*}{25} & L/D & $91.2 \mathrm{a}$ & $70.0 \mathrm{c}$ & $100.0 \mathrm{a}$ & $11.0 \mathrm{~d}$ & $0.0 \mathrm{f}$ & $0.0 \mathrm{e}$ & $0.0 \mathrm{c}$ & $60.0 \mathrm{~b}$ \\
\hline & $\mathrm{D}$ & $0.0 \mathrm{e}$ & $0.0 \mathrm{f}$ & $0.0 \mathrm{~d}$ & $0.0 \mathrm{e}$ & $0.0 \mathrm{f}$ & $0.0 \mathrm{e}$ & $0.0 \mathrm{c}$ & $0.0 \mathrm{c}$ \\
\hline
\end{tabular}

L: light condition; D: dark condition. CH: Cecropia hololeuca; CP: Cecropia pachystachya; CG: Cecropia glazioui; SG: Solanum gracillimum; SGL: Solanum granuloso-leprosum; ST: Solanum tabacifolium; CRF: Croton floribundus; MC: Miconia chamissois. Small letters compare means in each columm. Means followed by the same letter are not significant at 5\% level.

Table 2. Seed germination (\%) of eight tropical pioneer species in gap and under canopy condition at Mata de Santa Genebra, SE, Brazil.

\begin{tabular}{lcc}
\hline Species & Gap & Under canopy \\
\hline C. hololeuca & $83.0 \mathrm{a}$ & $2.0 \mathrm{~b}$ \\
C. pachystachya & $78.0 \mathrm{a}$ & $1.2 \mathrm{~b}$ \\
C. glazioui & $100.0 \mathrm{a}$ & $6.6 \mathrm{~b}$ \\
S. gracilimum & $50.0 \mathrm{a}$ & $0.0 \mathrm{~b}$ \\
S. granuloso-leprosum & $19.0 \mathrm{a}$ & $0.0 \mathrm{~b}$ \\
S. tabacifolium & $93.0 \mathrm{a}$ & $70.0 \mathrm{~b}$ \\
M. chamissois & $90.0 \mathrm{a}$ & $70.0 \mathrm{a}$ \\
C. floribundus & $12.5 \mathrm{a}$ & $7.5 \mathrm{a}$ \\
\hline
\end{tabular}

Small letters compare means between gap and under canopy conditions. Means followed by the same letter are not significant at $5 \%$ level.

incubation and stabilized after six weeks. Practically no germination occurred at constant temperatures either under light or darkness. Under alternating temperatures $S$. gracillimum and $S$. granulosoleprosum exhibited a positive response to light in almost all alternating temperatures. In contrast $S$. tabacifolium seeds were negatively photoblastic under $30 / 15,30 / 20$ and $30 / 25{ }^{\circ} \mathrm{C}$; at $30 / 10$ and
$35 / 10{ }^{\circ} \mathrm{C}$, those differences were not statistically significant and at $35 / 15^{\circ} \mathrm{C}$ higher germination was observed under the light/dark condition (table 1). The results recorded in the forest in generally agreed with the pattern observed under controlled conditions. S. gracillimum and S.granuloso-leprosum germinated only in the gap whereas $S$. tabacifolium had a high germination percentage in both conditions (table 2). The three Solanum species tolerated the reduction in the R:FR ratio to 0.6 with respect to percentage of germination. At 0.1, S. tabacifolium was not affected while $S$. gracillimum and $S$. granuloso-leprosum had their germination completely inhibited (table 3 ).

Due to the low availability of seeds, few experiments were performed with Croton floribundus and Miconia chamissois. High percentages of germination were obtained at $30 / 15^{\circ} \mathrm{C}$ and $30 / 20^{\circ} \mathrm{C}$ in both light/dark and dark conditions for $C$. floribundus and $30 / 20^{\circ} \mathrm{C}$ light/dark for M. chamissois. At a constant temperature $\left(25^{\circ} \mathrm{C}\right)$, the germination of $C$. floribundus seeds was completely inhibited (table 1). Nevertheless, when testa and endosperm of $C$. floribundus seeds were removed, $100 \%$ of embryos germinated after 3 or 4 days (radicle elongation and 
Table 3. Seed germination (\%) of seven tropical pioneer species under different $\mathrm{R}: F R$ ratios.

\begin{tabular}{lcc}
\hline & \multicolumn{2}{c}{$\mathrm{R}: \mathrm{FR}$} \\
\cline { 2 - 3 } Species & 0.6 & 0.1 \\
\hline C. hololeuca & 83.0 & 0.0 \\
C. pachystachya & 85.0 & 3.0 \\
C. glazioui & 48.0 & 0.0 \\
S. gracilimum & 85.0 & 0.0 \\
S. granuloso-leprosum & 54.0 & 0.0 \\
S. tabacifolium & $82.0 \mathrm{a}$ & $79.0 \mathrm{a}$ \\
M. chamissois & $70.0 \mathrm{a}$ & $57.0 \mathrm{a}$ \\
\hline
\end{tabular}

Small letters compare means of different R:FR ratios. Means followed by the same letter are not significant at $5 \%$ level.

greening of cotyledons under light treatment - data not shown). M. chamissois exhibited a strict positive photoblastic pattern. At $30 / 20^{\circ} \mathrm{C}$ and $25^{\circ} \mathrm{C}$, germination in the dark was completely inhibited (table 1).

In the forest, germination of seeds of $C$. floribundus was low both in the gap and under the canopy. By contrast, high germination occurred in both conditions for M. chamissois seeds (table 2). Reduction in the R:FR ratio did not restrict germination of M. chamissois seeds (table 3 ).

\section{Discussion}

Many pioneer species produce small seeds $(M$. chamissois $=0.09, S$. tabacifolium $=1.13, S$. granuloso-leprosum $=1.45, S$. gracillimum $=1.62$, C. hololeuca $=3.76, C$. pachystachya $=0.913, C$. glazioui $=1.84$ and $C$. floribundus $=39.95 \mathrm{mg} . \mathrm{seed}^{-1}$ dry mass, respectively). In contrast to temperate species, where seed dormancy is frequent, seeds of tropical species usually germinate after dispersal. In temperate plants hardness and a water-impermeable seed coat seem to be the major dormancy causing factors in some species (mechanical dormancy according to Baskin \& Baskin 1989). This appears to be true for species of late succession, but not for pioneers. Several pioneer species have mechanisms that delay or restrict germination. Among them, light is the most common and may be the principal factor influencing dormancy in seeds (Pons 1992).

The response of seeds to $\mathrm{R}$ and FR light and the effect of leaves on the R:FR ratio of the transmitted light underlies the perception of canopy shading with ecological implications for seed dormancy and germination. Leaf canopy reduces the Photon Flux Density (PFD) mainly in the photosynthetically active part of the spectrum $(400-700 \mathrm{~nm})$ due to the strong absorption by chlorophyll. Hence, light under canopy is rich in FR and poor in R (Smith 1982). Light with low R:FR ratios causes a low fraction of phytocrome in the far red (Pfr form) to the total phytocrome (Pfr:Ptot ratio), resulting in a Pfr level which may be below the threshold for the breaking of dormancy (Frankland \& Poo 1980). Use of leaves as filters resulted in reduced germination compared to unfiltered light controls in many light requiring seeds (Stoutjesdijk 1972, King 1975, Gorski 1975, Silvertown 1980).

The photoreceptor phytochrome present in the seeds functions as a device to detect shade produced by pre-existing trees and can respond by delaying germination. Only when gaps are formed in the vegetation the dormancy of the seeds can be broken by the higher Pfr:Ptot ratio established by full sunlight thereby allowing the seed to germinate (Frankland \& Poo 1980).

Gaps are important for the regeneration of many plants from seeds (mainly pioneer species) since shading and other competitive effects of established plants can restrain growth and reduce the survival of young seedlings (Grubb 1977, Fenner 1978, Pons \& Van der Toorn 1988). Germination of seeds of tropical pioneers affected by shade of leaf canopies is known for several species such as Cecropia glazioui (Valio \& Joly 1979), Cecropia obtusifolia, Piper auritum, Heliocarpus donnell-smithii (VazquezYanes \& Orosco-Segovia 1982, 1987, 1993, 1996).

The seeds of all species studied here were photoblastic (with the exception of Croton floribundus which is the species with the largest seed). Under light, germination occurred under all temperature treatments, but, in darkness at constant temperature, germination was drastically inhibited. Temperature fluctuations can break dormancy in many seeds and in some cases light can substitute for this requirement (Totterdel \& Roberts 1980). It seems that alternate temperatures interfere with Pfr action (Probert $\&$ Smith 1986). According to these authors, the capacity for dark germination at alternating temperatures may be explained by the sensitivity of some 
seeds to low levels of pre-existing Pfr. Temperature may also affect the response of the seeds to the R:FR ratio possibly affecting the treshold level for breaking dormancy (Pons \& Van der Toorn 1988). This could be the explanation for the germination percentages found under alternate temperatures and not in constant temperature.

The ecological significance of the effect of temperature range for several different species is known. Thompson \& Grime (1983) found an increased germination with increasing amplitude values for Urtica dioica. In this paper, amplitudes varying from 5 to $25^{\circ} \mathrm{C}$ did not produce conclusive responses for all studied species. Nevertheless the requirement for alternating temperatures and light represents an adaptation of small-seeded species which ensures that germination can occur near the soil surface in vegetation gaps.

Germination of Croton floribundus seeds was inhibited under constant temperature either in light or darkness, but high percentages of germinated seeds were obtained in alternating temperatures. It is possible that for these seeds alternating temperatures are required to activate hormonal metabolism and thus increase potential growth of the radicle and hydrolysis of cell walls in the endosperm facilitating the emergence of the radicle. Removal of the seed coat and endosperm resulted in a fast and high germination of the isolated embryos.

The range of maximum and minimum temperatures under the canopy is within the range of alternating temperatures studied in this report. Thus, temperature does not appear to be responsible for the absence of germination of these species in natural conditions. Low R:FR ratio appears to be the limiting factor affecting germination.

The drastic reduction of germination under low $\mathrm{R}: \mathrm{FR}$ ratio (0.1) as well as under the canopy suggest a strong influence of light quality on the germination process of these species. Solanum tabacifolium and Miconia chamissois did not follow this pattern. Both species had high germination percentages under low R:FR ratio (both in incubators and under canopy). Probably the levels of pre-existing Pfr are enough to the germinating process in these species.

Phytochrome is the pigment involved in the perception and response of many physiological processes. In view of a possible interaction of phyto- chrome and other factors, the interpretation of the light responses with regards to its ecological significance becomes complex. In conclusion, the absence of these species under the canopy can be due to reduced germination or mortality of the young seedlings due to their shade-intolerance.

Acknowledgements - The authors thank Fundação J.P. Oliveira, for the facilities and support in the Mata de Santa Genebra.

\section{References}

BASKIN, J.M. \& BASKIN, C.C. 1989. Physiology of dormancy and germination in relation to seed bank ecology. In Ecology of soil seed banks. (M.A. Leck, V.T. Parker \& R.L. Simpson eds.). Academic Press, San Diego, p.53-66.

CASTELLANI, T.T. \& STUBBLEBINE, E.W.H. 1993. Early secondary succession after disturbance by fire in a semideciduous tropical forest. Revista Brasileira de Botânica 16:181-203.

FENNER, M. 1978. A comparison of the abilities of colonizers and closed turf species to establish from seed in artificial swards. Journal of Ecology 66:953-963.

FRANKLAND, B. \& POO, W.K.1980. Phytochrome control of seed germination in relation to natural shading. In Photoreceptors and plant development (J. De Greef, ed.). University Press, Antwerpen, p.357-366.

GANDOLFI, S. 2000. História natural de uma floresta estacional semidecidual no município de Campinas (São Paulo, Brasil). Tese de doutorado, Universidade Estadual de Campinas, Campinas.

GORSKI, T. 1975. Germination of seeds in the shadow of plants. Physiologia Plantarum 34:342-346.

GROMBONE-GUARATINI, M.T. 1999. Dinâmica de uma floresta estacional semidecidual: o banco, a chuva de sementes e o extrato de regeneração. Tese de doutorado, Universidade Estadual de Campinas, Campinas.

GRUBB, P.J. 1977. The maintenance of species richness in plant communities: the importance of the regeneration niche. Biological Review 2:107-145.

HOLTHIJZEN, A.M.A. \& BOERBOOM, J.H.A. 1982. The Cecropia seed bank in the Surinam lowland rainforest. Biotropica 14:62-68.

KING, T.J. 1975. Inhibition of seed germination under leaf canopies in Arenaria serpyllifolia, Veronica arvensis and Cerastium holosteoides. New Phytologist 75:87-90.

PONS, T.L. 1992. Seed responses to light. In Seeds - The ecology of regeneration in plant communities.(M. Fenner, ed.). CAB International, New York, p.259-284.

PONS, T.L. \& VAN DER TOORN, J. 1988. Establishment of Plantago lanceolata L. and Plantago major L. among grass. I. Significance of light for germination. Oecologia 75:394-399.

PROBERT , R.J. \& SMITH, R.D. 1986. The joint action of phytochrome and alternating temperatures in the control of seed germination in Dactylis glomerata. Physiologia Plantarum 67:299-304. 
SILVERTOWN, J. 1980. Leaf-canopy-induced seed dormancy in a grassland flora. New Phytologist 85:87-90.

SMITH, H. 1982. Light quality, photoperception and plant strategy. Annual Review of Plant Physiology 33:481-518.

STOUTJESDIJK, P. 1972. Spectral transmission curves of some types of leaf canopies with a note on seed germination. Acta Botanica Neerlandica 21:185-191.

STUTZ DE ORTEGA, L.C. 1990. Floristic study of several secondary states of forests in Alto Parana (Eastern Paraguay): structure, floristic composition and regeneration: analysis of five states of secondary successions. Candollea 45:81-124.

SWAINE, M.D. \& WHITEMORE, T.C. 1988. On the definition of ecological species groups in tropical rain forests.Vegetatio 75:81-86.

THOMPSON, K. \& GRIME, J.P. 1983. A comparative study of germination responses to diurnally-fluctuating temperatures. Journal of Applied Ecology 20:141-156.

TOTTERDEL, S. \& ROBERTS, E.H.1980. Characteristics of alternating temperatures which stimulate loss of dormancy in seeds of Rumex obtusifolius L. and Rumex crispus L. Plant Cell and Environment 3:3-12.
VALIO, I.F.M. \& JOLY C.A. 1979. Light sensitivity of the seeds on the distribution of Cecropia glaziovi Snethlage (Moraceae). Zeitschrift Pflanzenphysiologie 91:371-76.

VAN DER PIJL, L. 1982. Principles of dispersal in higher plants. Springer-Verlag, Berlin.

VAZQUEZ-YANES, C. \& OROZCO-SEGOVIA, A. 1982. Seed germination of a tropical rain forest pioneer tree Heliocarpus donnell-smithii in response to diurnal fluctuation of temperature. Physiologia Plantarum 56:295-298.

VAZQUEZ-YANES, C. \& OROZCO-SEGOVIA, A. 1987. Light gap detection by photoblastic seeds of Cecropia obtusifolia and Piper auritum, two rain forest trees. Biologia Plantarum 29:234-236.

VAZQUEZ-YANES, C. \& OROZCO-SEGOVIA, A. 1993. Patterns of seed longevity and germination in the tropical rainforest. Annual Review of Ecological Systematics 24:69-87.

VAZQUEZ-YANES, C. \& OROZCO-SEGOVIA, A. 1996. Physiological ecology of seed dormancy and longevity. In Tropical forest plant ecophysiology (S.S. Mulkey, R.L Chazdon, \& A.P. Smith, eds.). Chapman \& Hall, London, p.535-558. 